\title{
A characterisation of the geothermal potential of the Muschelkalk deposits' location, with the prospective of its utilization in balneology and recreation (southern Poland)
}

\author{
Marzena Gancarz \\ AGH University of Science and Technology, Faculty of Drilling, Oil and Gas, Department of Gas Engineering; \\ al. A. Mickiewicza 30; 30-059 Krakow, Poland; e-mail: mgancarz@agh.edu.pl \\ (C) 2015 Authors. This is an open access publication, which can be used, distributed and reproduced in any medium according \\ to the Creative Commons CC-BY 4.0 License requiring that the original work has been properly cited.
}

Received: 19 June 2015; accepted: 11 January 2016

\begin{abstract}
Analysis of the geothermal potential of the Muschelkalk deposits was carried out from the point of view of utilising hot groundwater in balneology and recreation. As a result of a number of analytical studies, the area situated in the southern part of the Polish Lowland was selected as one of the prospective areas for the location of geothermal intakes. This area encompasses the southern part of the Fore-Sudetic Monocline, the southern part of the Łódź Trough and a small section of the Miechowska Trough. The deposits are buried at depths of between $500 \mathrm{~m}$ b.s.l and $1500 \mathrm{~m}$ b.s.l. Their thickness varys from $100 \mathrm{~m}$ to $300 \mathrm{~m}$. The temperature at the top in most cases is about $30-50{ }^{\circ} \mathrm{C}$. TDS in most cases does not exceed $60 \mathrm{~g} / \mathrm{dm}^{3}$ Mineralised water flood tide is from $0.4 \mathrm{~m}^{3} / \mathrm{h}$ to $13.8 \mathrm{~m}^{3} / \mathrm{h}$ Porosity is between $9 \%$ and $23 \%$, and permeability is from $25 \mathrm{mD}$ to $340 \mathrm{mD}$. As a result of the analyses, the most favourable conditions for development of balneotherapy and recreation in the Muschelkalk deposits in the three locations of the selected area were found to be where the boreholes Trzebnica IG-1 (first area), Wierzchlas 3, Rzeki IG-1 (second area) and Trzonów 2 (third area) were located.
\end{abstract}

Keywords: Muschelkalk, geothermal water, balneology, recreation

\section{INTRODUCTION}

The concept of utilising subsurface thermal brines has been developing since the 19th century. There are 37 quite popular and traditional spas in the Sudety and the Carpathian Mountains, where mineral and thermal waters from drilling wells and springs are used. Never the less, these water sources in Poland seem to be insufficient, which suggests the need for more locations to be used as thermal brines in balneology and recreation. The usefulness of geothermal waters for medicinal or recreational purposes is determined mainly by parameters such as their temperature or TDS. The conditions that must be met in order to use geothermal water for recreation and balneology also include efficiency of the water intake, water pressure and a favourable depth of occurrence of the aquifer (Górecki et al 1996, Kępińska 2011). The reservoir temperature increases with depth, but the producing conditions deteriorate. The temperature increases with increasing TDS and decreasing reservoir properties. Increasing TDS raises the water's viscosity, which, in turn, lowers the discharge (Górecki et al 2000, Bujakowski \& Barbacki 2004, Barbacki 2010). 


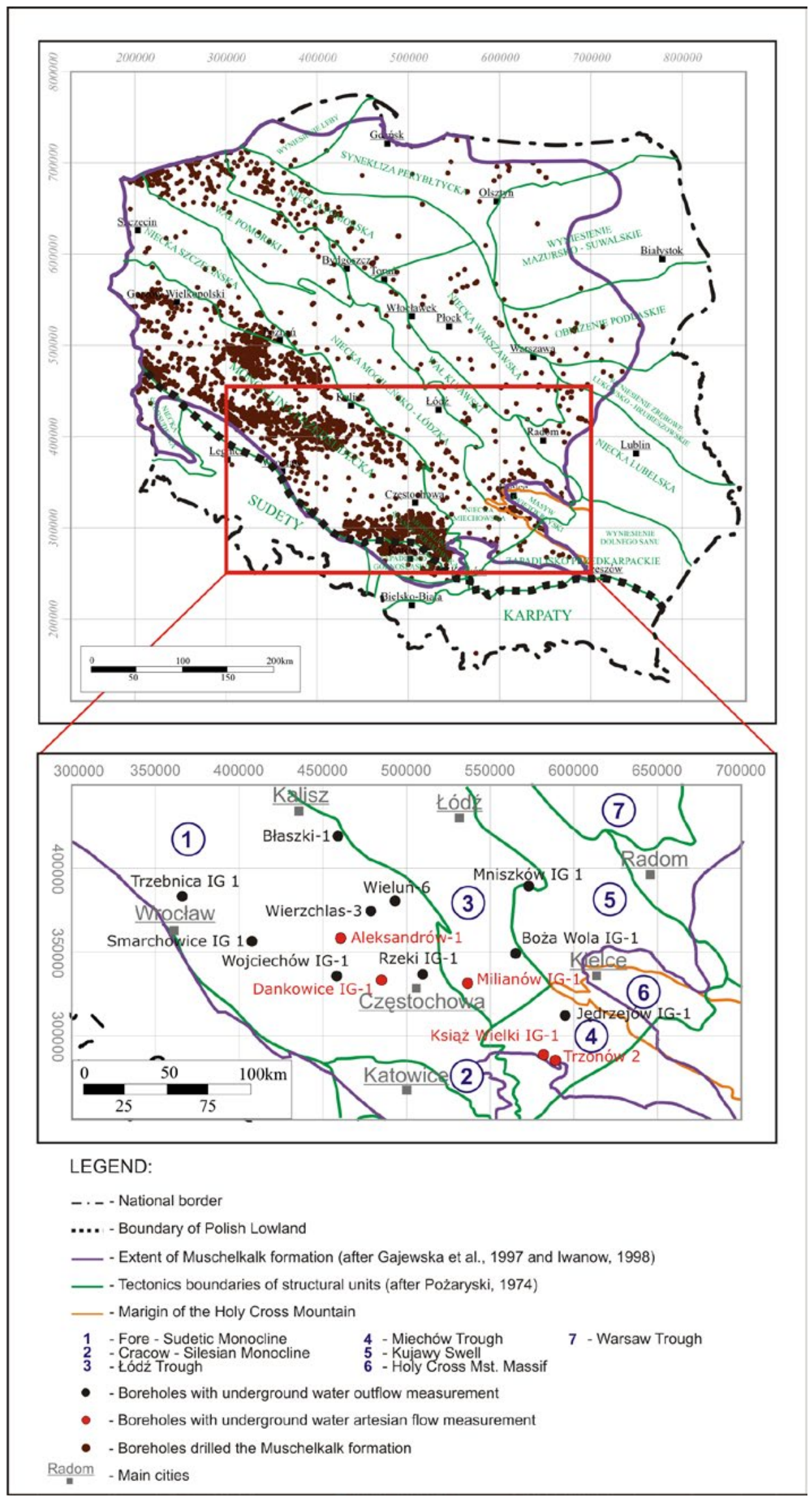

Fig. 1. Location map of the study area 
Requirements for geothermal water intake location for use in balneology and recreation include: thermal parameters of the water (temperatures $>24^{\circ} \mathrm{C}$ ), TDS of the water (a maximum of $50 \mathrm{~g} / \mathrm{dm}^{3}$ ), porosity and permeability of the reservoir rocks (the highest possible) and the yield from the borehole (a minimum of $3 \mathrm{~m}^{3} / \mathrm{h}$ ) (Płochniewski 1990, Ponikowska 1995, Paczyński \& Płochniewski 1996, Rajchel 2006). For swimming and bathing, TDS of the water should be lower than $35 \mathrm{~g} / \mathrm{dm}^{3}$, and the temperature should be from $20^{\circ} \mathrm{C}$ to $30^{\circ} \mathrm{C}$. Therefore, deep subsurface brines, usually with higher TDS and water temperature, have to be mixed with fresh surface waters to meet the above requirements (Ponikowska 1995, Paczyński \& Płochniewski 1996).

An area that has good water conditions and parameters suitable for therapeutic and recreational use was selected based on the richest literature, and on all of the factors mentioned above.

\section{GEOLOGICAL SETTINGS}

The area selected for detailed structural-parametric and thermal modelling in terms of the preliminary assessment of the potential use of the thermal brines for balneology and recreation is located in southern Poland. This area encompasses a part of the Fore-Sudetic Monocline, a part of the Łódź Trough and a small section of the Miechowska Trough (Fig. 1).

The Middle Triassic sedimentary basin represented a continuation of the marine basin formed in the Upper Buntsandstein. In the initial period of the Middle Triassic, marine transgression proceeded and, as a result, most of the Polish Lowlands area was flooded during the entire Triassic age. In the Lower and Middle Muschelkalk, a basin was located with equalised subsidence, the thickness of which in the whole of western, central and southern Poland amounted to 150-200 m (Gajewska 1988). Not earlier than in the Upper Muschelkalk and the Lower Keuper, activity in the Middle Polish Trough became pronounced again, particularly in the Kujawy segment of the Trough, where the thickness of the deposits increased considerably. The total thickness of the Middle Triassic (Muschelkalk + Lower Keuper) deposits exceeds 1400 m in this region (Iwanow 1998).
The Muschelkalk deposits are divided into the Lower Muschelkalk, Middle Muschelkalk and Upper Muschelkalk (Senkowiczowa \& Szyperko-Śliwczyńska 1972). The Lower Muschelkalk are represented by three complexes: Marly layers, represented by the marls and marly limestones, Wavy layers, represented by marly limestones, with the marls and wavy clay interbeds, and Foamed layers, represented by limestones, mainly oolitic limestones, with recrystallised fauna. The Middle Muschelkalk is represented by dolomites, clay dolomites and anhydrites. The Upper Muschelkalk is represented by Glauconitic layers, composed of limestones, with clay interbeds and Ceratitic layers composed of claystones with limestone interlayers (Fig. 2) (Gajewska 1988, Gajewska \& Becker 2007).

\section{MATERIALS AND METHODS}

Analysis has been carried out stemming from scientific literature review, as well as the results of previous hydrogeological and petroleum geological research, based on well data (Department of Fossil Fuels, AGH University of Science and Technology, Polish Geological Institute PIG, Warsaw Database) and the evaluation of prospective subsurface thermal water zones usable for balneology and recreation purposes. Specifically, the evaluation presented here comes from such hydrogeological data as salinity and temperature of the subsurface brines and their borehole yield. This forms the primary selection and classification of hydrogeothermal zones useful for the above purposes, which brings attention to the prospects of utilizing these deep brines and potential reserves in the Muschelkalk deposits of the southern part of the Polish Lowland.

The most promising conditions (temperatures of water $>20^{\circ} \mathrm{C}$ and discharge $>3 \mathrm{~m}^{3} / \mathrm{h}$ ) occur in southern Poland (Fig. 1). Preliminary analyses revealed prospects for the location of geothermal water intakes for use in balneology and recreation in the Lower Muschelkalk formation, which seems to be a complex meeting the balneology and recreation requirements.

Determination of the prospective zones for the location of the geothermal water intakes for use in balneology and recreation, proceeded in two steps. 


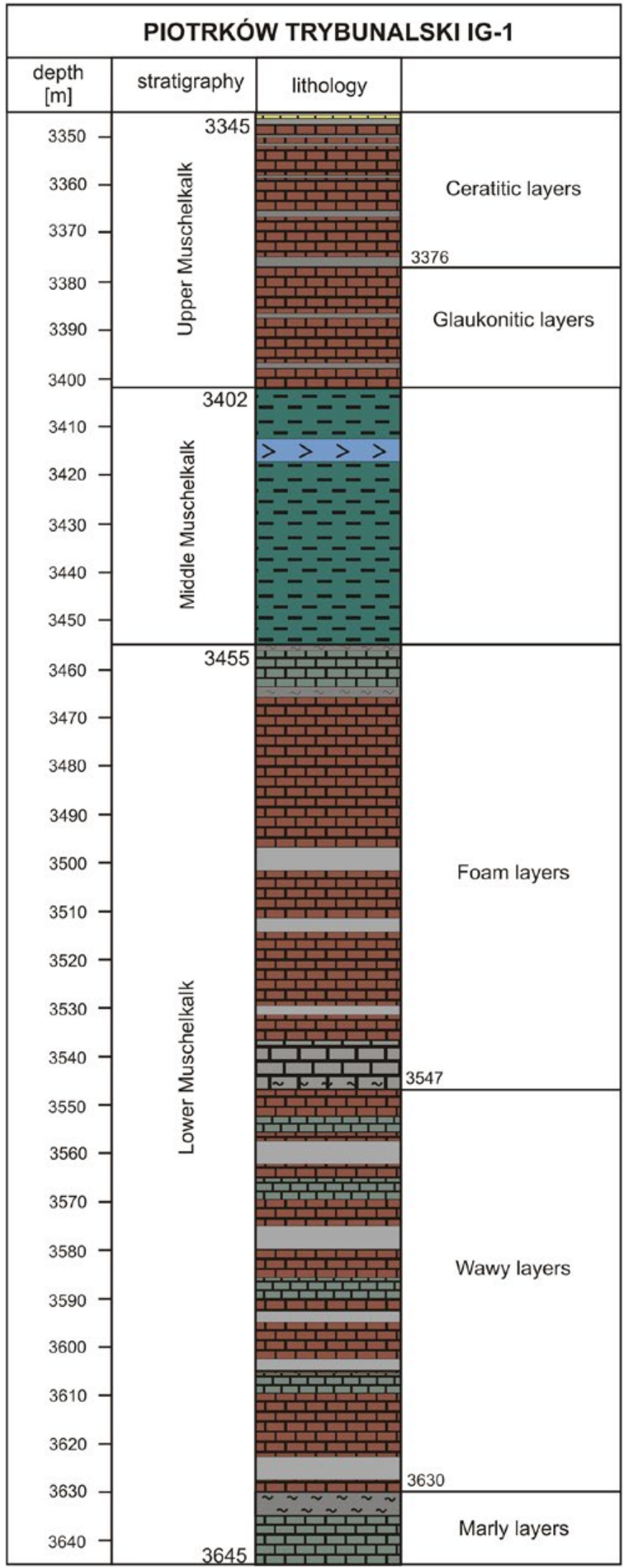

LEGEND

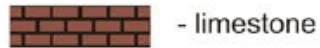

포도돋 - sandy limestone

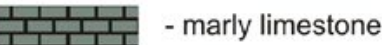

포모도 - clayly limestone

$\overline{-\overline{-}=-}$ - dolomitic clay

- clay

$>>\quad$ - anhydrite

- mudstone

Fig. 2. Lithological-stratigraphic profile of the Muschelkalk deposits in the Piotrków Trybunalski IG-1 borehole (after Gajewska \&Becker 2007) 
In the first step, the structural-thicknesses and parametric (temperature, TDS, porosity, permeability and yield) analysis was carried out.

Results were displayed in the form of maps:

- structural map of the top surfaces of the Muschelkalk formation,

- map of the total thickness of the Muschelkalk formation,

- map of the temperature ranges in the top part of the Muschelkalk formation,

- map of the TDS of reservoir water in the top part of the Muschelkalk formation,

- map of the total porosity of the Muschelkalk formation,

- map of the yield of the borehole from the Muschelkalk formation.

The second step consisted of the final phase of the analysis. In this step, the prospective area was designated, based on the following assumptions: a temperature of $30^{\circ} \mathrm{C}$ at the top of Muschelkalk formation - assuming that the temperature on the transmission losses will be a maximum of $5^{\circ} \mathrm{C}$, TDS of water $70 \mathrm{~g} / \mathrm{dm}^{3}$ - because the water could be mixed, yield of borehole - a minimum of $3 \mathrm{~m}^{3} / \mathrm{h}$.

\section{RESULTS (Figs 3-9)}

The studied area is located at altitudes from about $120 \mathrm{~m}$ a.s.l. in Wrocław and Kalisz and about 300 m a.s.l. in Kielce and Katowice.

The top surface of the Muschelkalk formation is located at altitudes from some tens of metres a.s.l. in the Silesian-Kraków Monocline, to below $-4000 \mathrm{~m}$ a.s.l. in the Łódź Trough and below $-500 \mathrm{~m}$ a.s.l. in the largest part of the area of the Muschelkalk occurrence. The deepest locations (below $-2000 \mathrm{~m}$ a.s.l.) were observed in the Łódź Trough (Fig. 3).

The total thickness of the Muschelkalk formation is relatively low and varies from several metres to $>300 \mathrm{~m}$, but in most cases it exceeds $100 \mathrm{~m}$. In the Miechowska Trough, the thickness does not exceed $50 \mathrm{~m}$. The thicker strata were observed in the Łódź Trough and the Fore-Sudetic Monocline (Fig. 4).

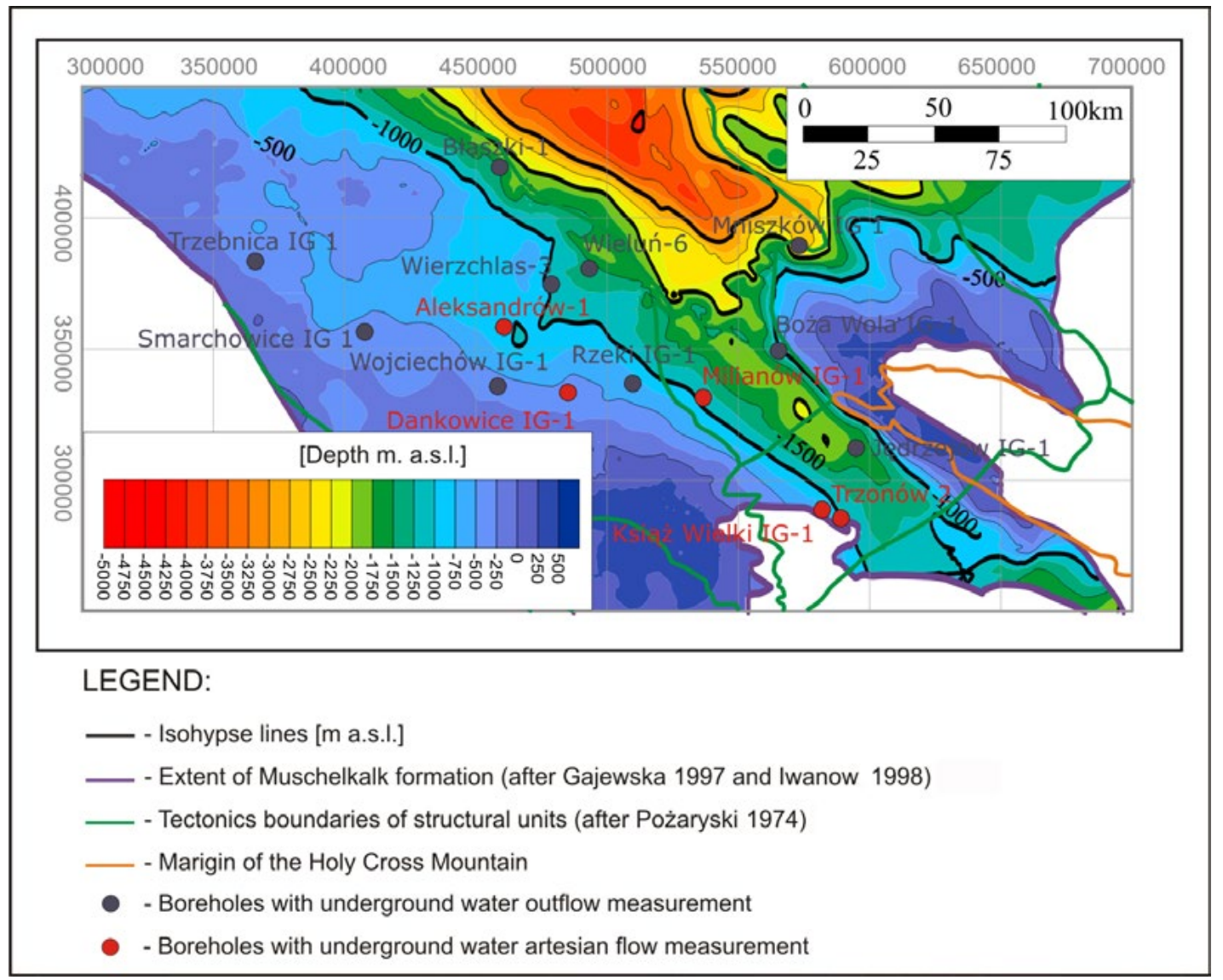

Fig. 3. Structural map of the top surface of the Muschelkalk formation in the selected area 


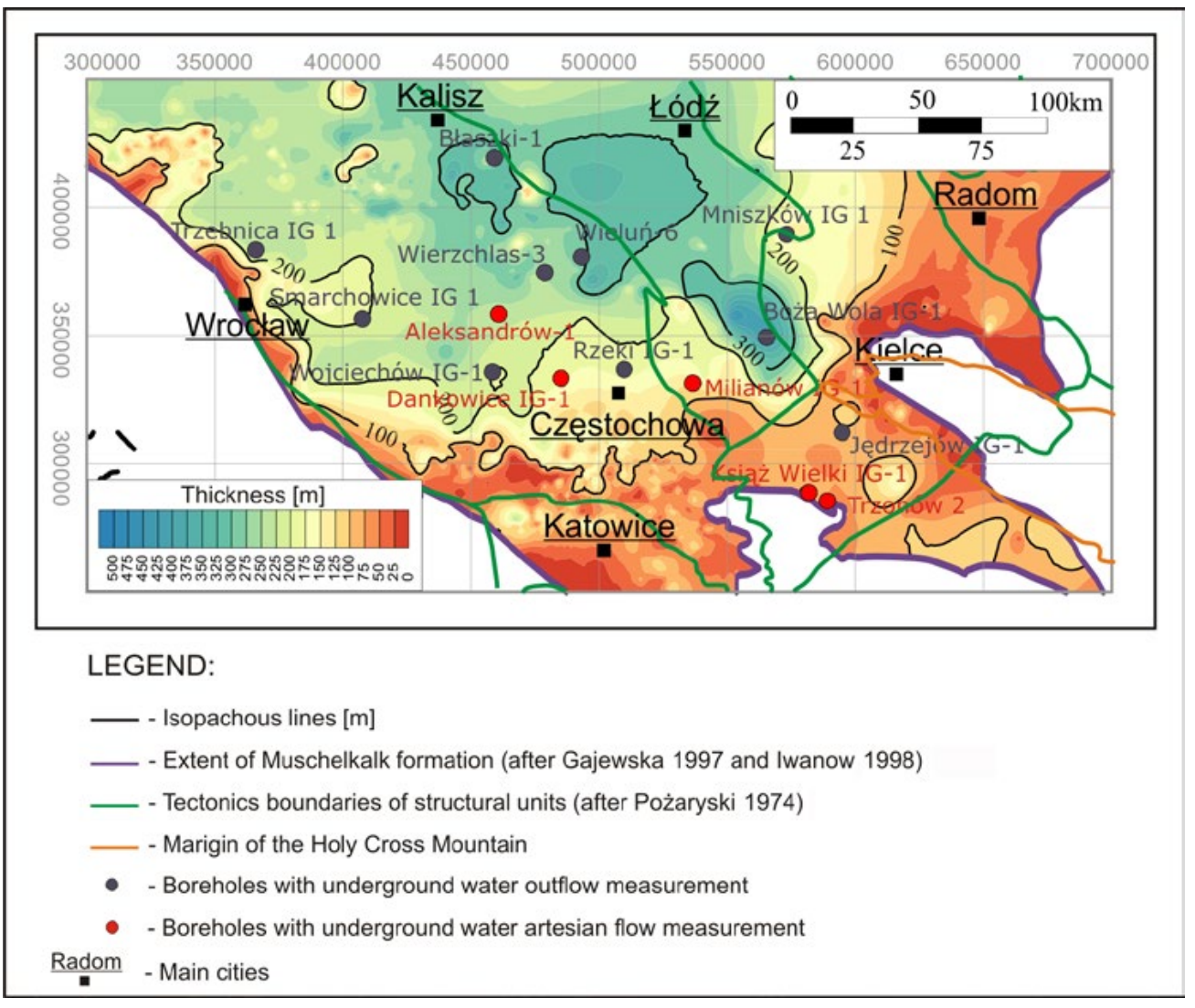

Fig. 4. Map of total thickness of the Muschelkalk formation in the selected area

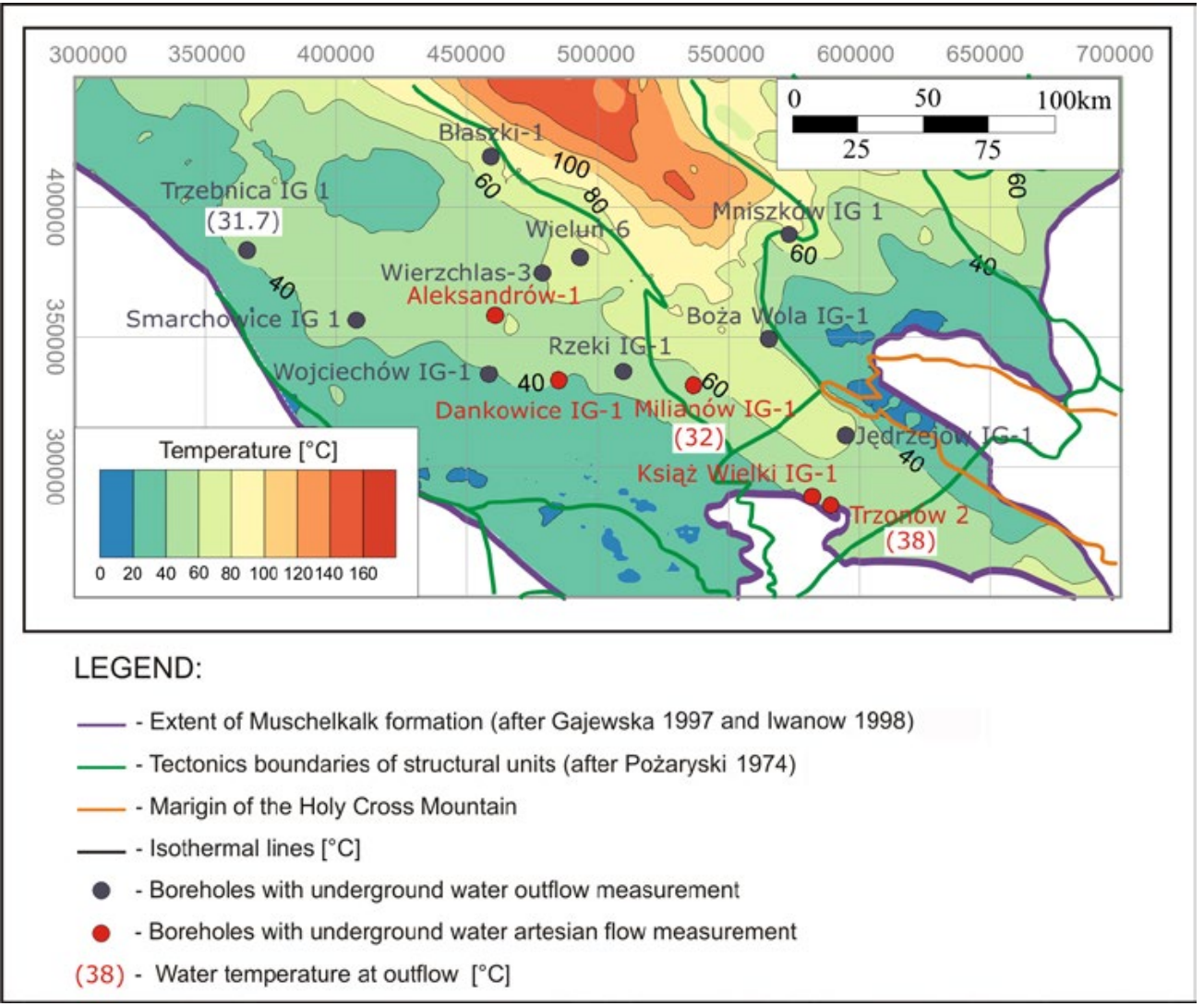

Fig. 5. Map of temperature in the top part of the Muschelkalk formation in selected area 


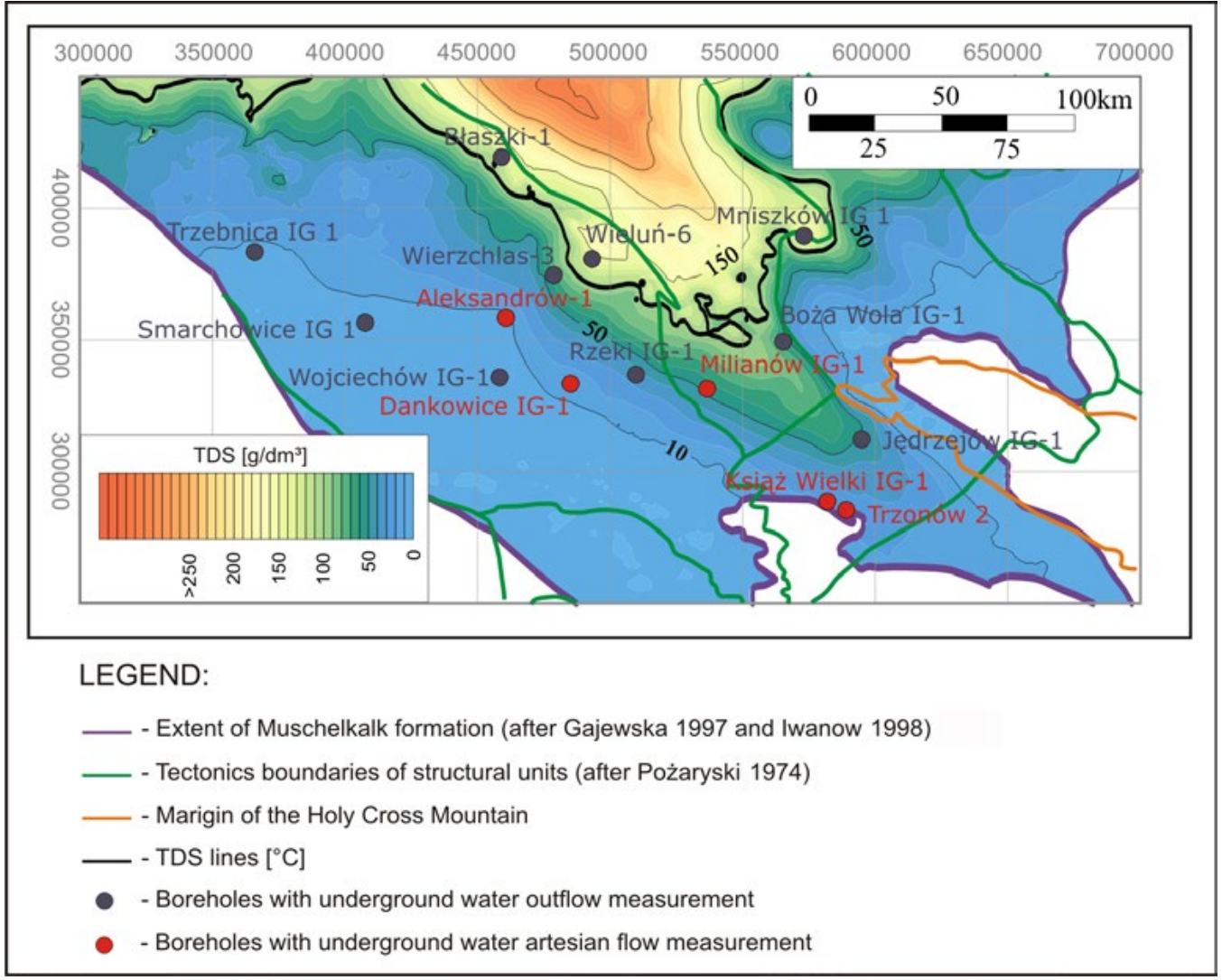

Fig. 6. Map of TDS of reservoir water in the top part of the Muschelkalk formation in selected area

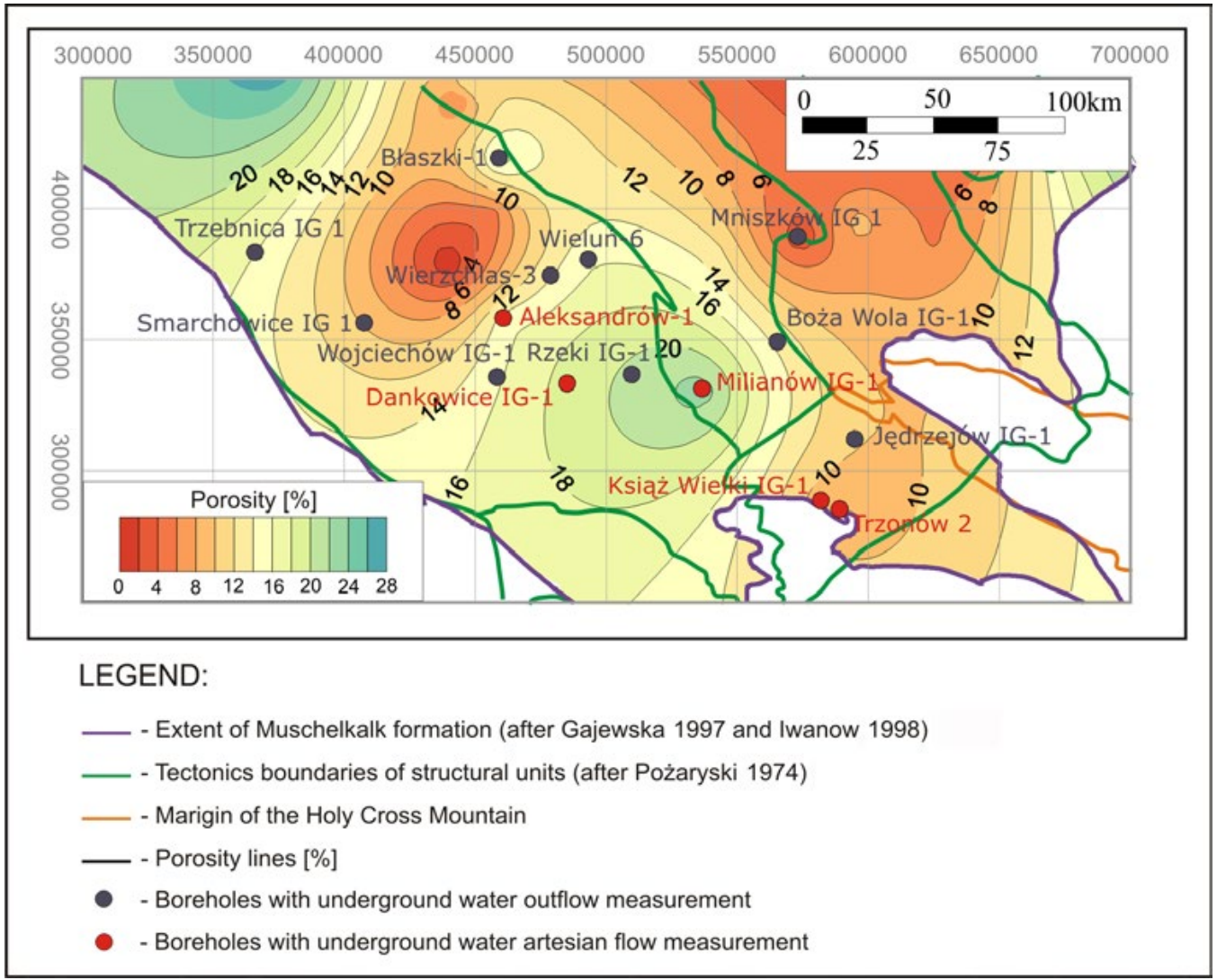

Fig. 7. Map of total porosity of the Muschelkalk formation in selected area 


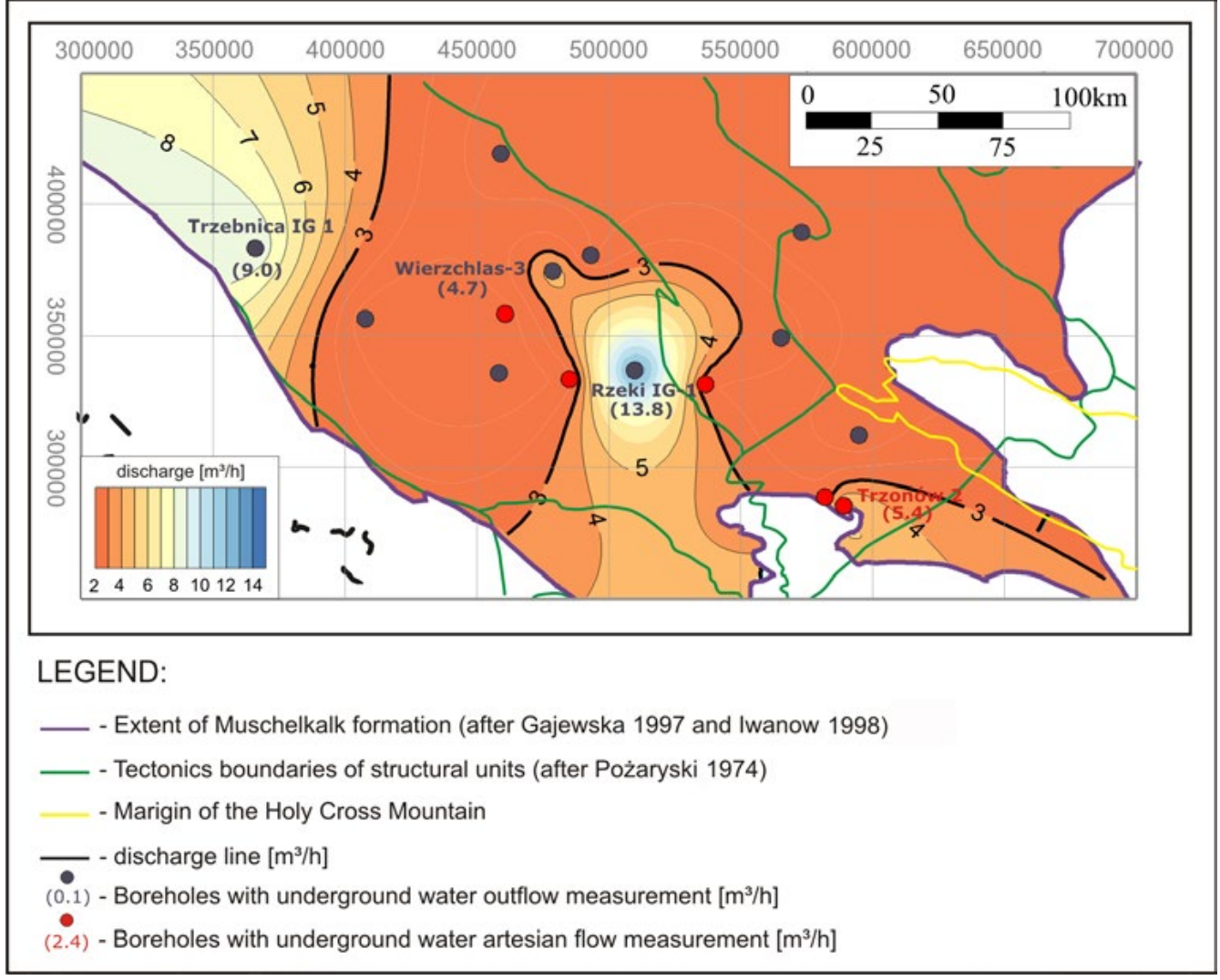

Fig. 8. Map of borehole yield from the Muschelkalk formation in selected area

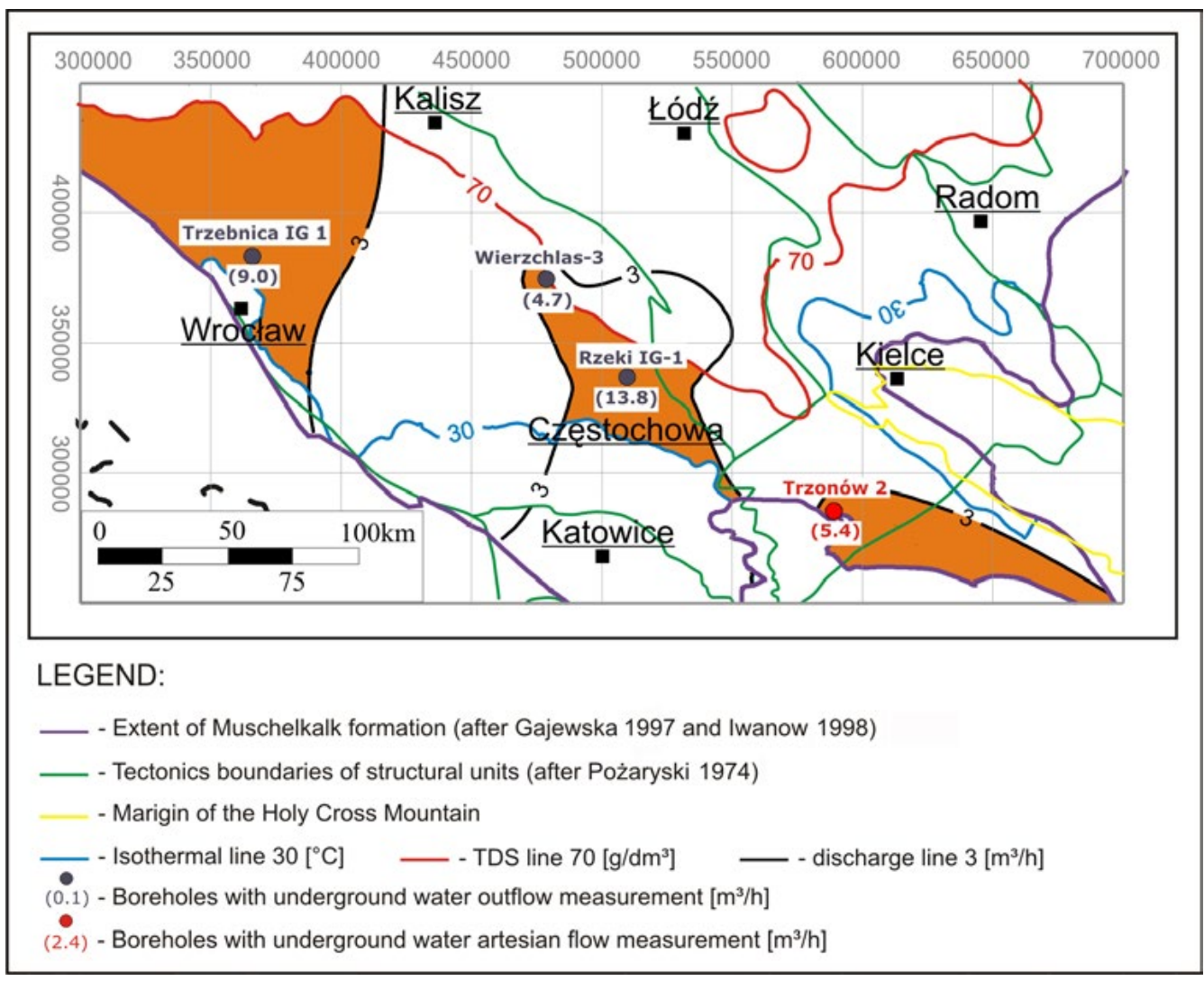

Fig. 9. Prospective areas for location of geothermal intakes for use in balneology and recreation 
Temperatures of the top part of Muschelkalk strata are closely related to the depth of occurrence. Variability of the temperature field is high and changes from a dozen degrees centigrade (marginal parts of an aquifer) to higher than $120^{\circ} \mathrm{C}$ in the Łódź Trough, below $60^{\circ} \mathrm{C}$ in the Fore-Sudetic Monocline and higher than $40^{\circ} \mathrm{C}$ in both the Miechów and the Warsaw Trough. In the remaining structural units, temperatures do not exceed $80^{\circ} \mathrm{C}$ (Fig. 5).

The TDS in these formations is closely linked to the depth of occurrence and changes from a few gram per cubic decimeter (in the marginal parts

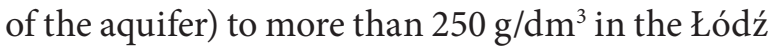
Trough. Generally, TDS values in the Muschelkalk ground waters are more than $50 \mathrm{~g} / \mathrm{dm}^{3}$ (Fig. 6). The high TDS of the ground waters reservoired in the Muschelkalk formation suggests their possible use for therapeutics and recreational purposes. However, more detailed assessment is impossible, due to the lack of hydrochemical data.

The total porosity of the Muschelkalk formation varies from severalto $28 \%$. Generally, the porosity value is higher than $5 \%$. In the Miechowska Trough, the porosity is about $10 \%$, and in the northern and southern part of the Fore-Sudetic Monocline, the porosity is higher than $10 \%$. The porosity in the Łódź Trough varies from $6 \%$ to 22\% (Fig. 7) (Gancarz 2015).

The borehole yield from the Muschelkalk formation varies from several cubic meter per hour to almost $14 \mathrm{~m}^{3} / \mathrm{h}$. In most places, the discharge does not exceed $3 \mathrm{~m}^{3} / \mathrm{h}$. In the small southern part of the Miechowska Trough, the yield is higher than $3 \mathrm{~m}^{3} / \mathrm{h}$. In the northern part of the Fore-Sudetic Monocline, the discharge varies from $3 \mathrm{~m}^{3} / \mathrm{h}$ to $9 \mathrm{~m}^{3} / \mathrm{h}$, and in the southern part of the Fore-Sudetic Monocline, the yield varies from $3 \mathrm{~m}^{3} / \mathrm{h}$ to above $13 \mathrm{~m}^{3} / \mathrm{h}$. The discharge in the Łódź Trough is relatively low (Fig. 8).

\section{DISCUSSION}

The results of structural and parametric analysis for the pre-indicated area (Fig. 1) made it possible to identify the prospective location for geothermal intakes for balneology and recreational use.

The main requirements for the use of water in balneology and recreation is its temperature at the outflow (a minimum of $24^{\circ} \mathrm{C}$ for recreation and a minimum of $28^{\circ} \mathrm{C}$ for balneology), its TDS (a maximum of $30 \mathrm{~g} / \mathrm{dm}^{3}$ for recreation and a maximum of $50 \mathrm{~g} / \mathrm{dm}^{3}$ for balneology) and its borehole yield (a minimum of $3 \mathrm{~m}^{3} / \mathrm{h}$ ).

A temperature above $30^{\circ} \mathrm{C}$ in the top surface of the Muschelkalk deposits occurs in $90 \%$ of the selected area (Figs 5, 9). Because the geothermal water could be mixed, a TDS of below $70 \mathrm{~g} / \mathrm{dm}^{3}$ was assumed for the selected area. This TDS occurs in $60 \%$ of the study area (Figs 6,9 ). Only four boreholes in the Muschelkalk deposits have a discharge of above $3 \mathrm{~m}^{3} / \mathrm{h}$ : Trzebnica IG-1 $\left(9 \mathrm{~m}^{3} / \mathrm{h}\right)$, Wierzchlas $3\left(4.7 \mathrm{~m}^{3} / \mathrm{h}\right)$, Rzeki IG-1 $\left(13.8 \mathrm{~m}^{3} / \mathrm{h}\right)$ and Trzonów $2\left(5.4 \mathrm{~m}^{3} / \mathrm{h}\right)$ (Figs 8,9$)$.

Based mostly on the temperature of the water, its TDS and yield of the borehole, three locations with good water conditions and parameters suitable for use in therapeutic and recreational activities were selected.

The first and second areas cover part of the Fore-Sudetic Monocline, the firstlocated between Kalisz and Wrocław and the second near Częstochowa. The third area covers a small part of the Miechów Trough.

The Trzebnica IG-1 borehole is located in the first area (Fig. 9), where, from the Muschelkalk deposits (at a depth of 646-844 m), the water outflow at a temperature of $31.7^{\circ} \mathrm{C}$ was $9 \mathrm{~m}^{3} / \mathrm{h}$. The water is of the type $\mathrm{SO}_{4}-\mathrm{Cl}-\mathrm{Ca}-\mathrm{Na}$, and the TDS is $3.9 \mathrm{~g} / \mathrm{dm}^{3}$.

The Wierzchlas 3 and Rzeki IG-1 boreholes are located in the second area (Fig. 9). From Wierzchlas 3, from the Muschelkalk deposits (at a depth of $1330-1337 \mathrm{~m}$ ), water outflow was $4.3 \mathrm{~m}^{3} / \mathrm{h}$. The TDS of this water is near $70 \mathrm{~g} / \mathrm{dm}^{3}$. This borehole has a low outflow and very high TDS, and was excluded from the selected area. From Rzeki IG-1, from the lower and middle Muschelkalk deposits (at a depth of 966-1005.8 m), water outflow was $13.8 \mathrm{~m}^{3} / \mathrm{h}$. This borehole is located on the border of an artesian and subartesian zone. The water is of the type Cl-Na, and the TDS is $22 \mathrm{~g} / \mathrm{dm}^{3}$.

The Trzonów 2 borehole is located in the third area (Fig. 9). From the Muschelkalk deposits (at a depth of $1152-1155 \mathrm{~m})$, the artesian flow $\left(5.4 \mathrm{~m}^{3} / \mathrm{h}\right)$ was noted. The temperature of outflow water was $38^{\circ} \mathrm{C}$, and the TDS of the water was $11.6 \mathrm{~g} / \mathrm{dm}^{3}$.

\section{CONCLUSION}

Because of the water temperature, the TDS of the water and the yield of the borehole, the Muschelkalk 
deposits of the southern part of the Fore-Sudetic Monocline and a small part of the Miechowska Trough seem to be the most appropriate as geothermal intakes, for the use of geothermal water in balneology and recreation (Fig. 9).

Three locations were selected: 1 - part of the Fore-Sudetic Monocline, between Kalisz and Wrocław, 2 - part of the Fore-Sudetic Monocline, near Częstochowa, 3 - a small part of the Miechowska Trough, where the Trzonów 2 borehole is located (Fig. 9).

The characterisation of the hydrogeothermal parameters formed the basis for further analysis of the best location of geothermal intakes for use in balneology and recreation. The critical requirements for this location include: thermal parameters of the water (temperatures $>30^{\circ} \mathrm{C}$ ), the TDS of the water (a maximum of $70 \mathrm{~g} / \mathrm{dm}^{3}$, because the water could be mixed) and the yield of the borehole (a minimum of $3 \mathrm{~m}^{3} / \mathrm{h}$ ). Based on these requirements, the water in the Muschelkalk formation in selected areas could be used in balneotherapy and recreation.

Every one of these wells was drilled for petroleum purposes. As such, sufficient hydrogeological information is not available. Further investigation and reinterpretation of the existing data are required for a final assessment. To reiterate, hydrogeological tests should be carried out in boreholes located in separate areas, because the Muschelkalk deposits are among the most unidentified deposits of the Mesozoic formation. This is important for the reliability of well test data.

The paper has been prepared under the AGH UST statutory research grant No. 11.11.190.555.

\section{REFERENCES}

Barbacki A.P., 2010. Geological and technical aspects of geothermal energy utilization in South-East Poland. Environment Protection Engineering, 36, 1, 25-34.

Bujakowski W. \& Barbacki A., 2004. Potential for geothermal development in Southern Poland. Geothermics, 33, 7-18.

Gajewska I., 1988. Paleothickness and lithofacies of the Muschelkalk and Lower Keuper and the Middle Triassic paleotectonics in the Polish Lowlands. Geological Quarterly, 32, 1, 73-82.
Gajewska I., 1997. Trias środkowy (wapień muszlowy - kajper dolny). [in:] Marek S. \& Pajchlowa M., Epikontynentalny perm i mezozoik $w$ Polsce, Prace Państwowego Instytutu Geologicznego 153, Państwowy Instytut Geologiczny, Warszawa, 136-137.

Gajewska I. \& Becker A., 2007. Wyniki badań litologicznych i stratygraficznych utworów triasu środkowego i górnego. [in:] Leszczyński K. (red.), Piotrków Trybunalski IG-1, series: Profile głębokich otworów wiertniczych Państwowego Instytutu Geologicznego, 121, Państwowy Instytut Geologiczny, Warszawa, 41-42.

Gancarz M., 2015. Assessment of reservoir properties of the Muschelkalk deposits in the Polish Lowlands. Gospodarka Surowcami Mineralnymi - Mineral Resources Management, 31, 1, 65-80.

Górecki W. (red.), 1996. Studium możliwości inwestycyjnych nad wykorzystaniem energii geotermalnej $w$ zbiornikach dolnojurajskim $i$ dolnokredowym $w$ synklinorium mogileńsko-łódzkim na Niżu Polskim. Arch. ZSE, Kraków.

Górecki W. (red.), 2000. Analiza geologiczna i ocena zasobów wód $i$ energii geotermalnej $w$ formacjach jury środkowej i górnej oraz triasu na Niżu Polskim. Archiwum Zakładu Surowców Energetycznych - Akademia Górniczo-Hutnicza, Kraków.

Iwanow A., 1998. Trias środkowy. [in:] Dadlez R., Marek S. \& Pokorski J. (red.), Atlas paleogeograficzny epikontynentalnego permu i mezozoiku w Polsce, Wyd. Kartograficzne Polskiej Agencji Ekologicznej, Warszawa.

Kępińska B., 2011. Energia geotermalna w Polsce - stan wykorzystania, perspektywy rozwoju. Technika Poszukiwań Geologicznych Geotermia zrównoważony Rozwój, $1-2,7-18$.

Paczyński B. \& Płochniewski Z., 1996. Wody mineralne i lecznicze Polski. Państwowy Instytut Geologiczny, Warszawa.

Pajchlowa M. (red.), Epikontynentalny perm i mezozoik w Polsce. Prace Państwowego Instytutu Geologicznego CLIII, Warszawa.

Płochniewski Z., 1990. Perspektywy zwiększenia eksploatacji wód termalnych do celów balneologicznych i rekreacyjnych. [in:] Możliwości wykorzystania wód geotermalnych $w$ Polsce ze szczególnym uwzględnieniem synklinorium mogileńsko-łódzkiego: konferencja, Ślesin k. Konina, 26-27 październik 1990 rok, Kraków, Wyd. AGH, 209-217.

Ponikowska I. (red.), 1995. Medycyna uzdrowiskowa $w$ zarysie. WATEXT Agencja Wydawniczo-Reklamowa, Warszawa.

Pożaryski W., 1974. Podział obszaru Polski na jednostki tektoniczne. [in:] Budowa geologiczna Polski. T. 4, Tektonika. Cz. 1. Niż Polski, Instytut Geologiczny, Warszawa.

Rajchel L., 2006. Zastosowanie wód geotermalnych w balneoterapii i rekreacji. [in:] Górecki W. (red.), Atlas zasobów geotermalnych formacji mezozoicznej na Niżu Polskim, Akademia Górniczo-Hutnicza im. S. Staszica, Kraków, 50-51, 65-66.

Senkowiczowa H. \& Szyperko-Śliwczyńska A., 1972. Stratygrafia i paleogeografia triasu. Biuletyn Instytutu Geologicznego, 252, 9 . 